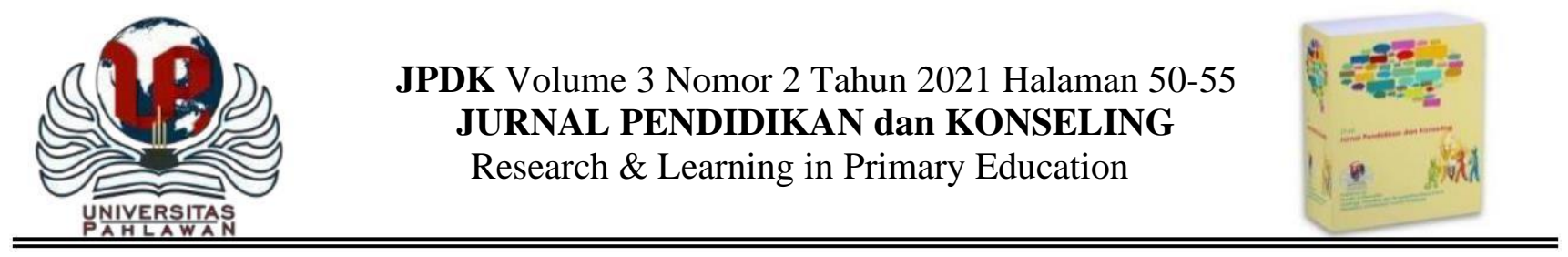

\title{
Analisis Kesiapan Guru Kelas Dalam Mengimplementasikan Pembelajaran Tematik Di Masa Pandemi Covid-19 di SD Pahlawan
}

\author{
Yanti Yandri Kusuma \\ Program Pendidikan Guru Sekolah Dasar \\ Fakultas Ilmu Pendidikan \\ Universitas Pahlawan Tuanku Tambusai \\ Email :zizilia.yanti@gmail.com
}

\begin{abstract}
Abstrak
Penelitian ini bertujuan untuk mendeskripsikan perencanaan, pelaksanaan, dan penilaian dalam mengimplementasikan pembelajaran tematik di Masa Pandemi Covid- 19 di kelas Dua Pahalwan Di Desaaa Ridan Permai. Penelitian ini merupakan penelitian kualitatif dengan jenis penelitian fenomenologi. Subjek dalam penelitian ini adalah guru kelas dua, siswa kelas dua, dan kepala sekolah. Objek penelitian ini berupa bentuk untuk kesiapan guru kelas dalam mengimplementasikan pembelajaran tematik di Masa Pandemi Covid19. Teknik pengumpulan data dalam penelitian ini menggunakan teknik observasi, wawancara, dan dokumentasi. Data dianalisis dengan menggunakan reduksi data, display data, dan penarikan kesimpulan. Uji keabsahan data menggunakan triangulasi teknik, sumber, dan waktu. Hasil penelitian ini menunjukkan bahwa guru kelas dua sudah membuat perencanaan pembelajaran berupa RPP. Pelaksanaan pembelajaran guru kelas satu sudah menggunakan pendekatan saintifik walau tidak urut $5 \mathrm{M}$ dan sudah mengacu kepada rambu-rambu dan prinsip pembelajaran tematik. Guru kelas satu menggunakan penilaian autentik yang menilai aspek sikap dengan observasi, aspek pengetahuan dengan tes tertulis serta penugasan, dan aspek keterampilan dengan unjuk kerja hasil pengamatan observasi yang peneliti lakukan, menemukan beberapa hal yang menjadi kendala dalam pelaksanaan pembelajaran tematik diantaranya dalam penyusunan RPP, karena format RPP kurikulum 2013 berbeda dengan kurikulum yang sebelumnya, kesulitan lain yang dialami oleh guru yakni dalam pelaksanaan proses pembelajaran tematik, dimana pada saat proses pembelajaran yang pada masa Pandemi Covid -19 banyak siswa yang tidak dapat secara keseluruhan mengikuti pembelajaran karna berbagai macam kendala seperti jaringan dari tempat mereka yang susah dapat jaringan dan kendala yang lain
\end{abstract}

Kata Kunci: Analisis Kesiapan Guru Kelas, pembelajaran Tematik

\begin{abstract}
This study aims to describe the planning, implementation, and assessment of implementing thematic learning during the Covid-19 Pandemic in class Dua Pahalwan di Desaaa Ridan Permai. This research is a qualitative research with the type of phenomenological research. The subjects in this study were second grade teachers, second grade students, and school principals. The object of this research is a form of classroom teacher readiness in implementing thematic learning during the Covid-19 Pandemic. Data collection techniques in this study use observation, interview, and documentation techniques. Data were analyzed using data reduction, data display, and drawing conclusions. Test the validity of the data using the triangulation of techniques, sources, and time. The results of this study indicate that the second grade teacher has made a lesson plan in the form of RPP. The implementation of first grade teacher learning has used a scientific approach even though it is not the 5M sequence and has referred to the signs and principles of thematic learning. First grade teachers use authentic assessment that assesses aspects of attitude by observation, aspects of knowledge by written tests and assignments, and aspects of skills with performance from observations of observations that researchers do, finding several things that become obstacles in implementing thematic learning, including in the preparation of lesson plans, because The RPP format for the 2013 curriculum is different from the previous curriculum, another difficulty experienced by teachers is in the implementation of the thematic learning process, where during the learning process during the Covid -19 Pandemic many students were unable to fully participate in learning
\end{abstract}


because of various kinds of constraints such as networks from where they find it difficult to network and other obstacles

\section{Keywords: Classroom Teacher Readiness Analysis, Thematic learning}

\section{PENDAHULUAN}

Pendidikan merupakan hal yang sangat mendasar bagi kehidupan manusia dan sebagai salah satu ujung tombak dari kemajuan suatu bangsa.Melalui pendidikan, manusia dapat memeroleh informasi yang sebelumnya dianggapmustahil.Peran pendidikan sangat penting kaitannya dengan perkembangan fisik, mental serta perilaku seorang individu.

Pendidikan bermanfaat bagi manusia untuk mengembangkan dirinya agar mampu menghadapi perubahan yang terjadi akibat perkembangan ilmu pengetahuan. Saat ini, perkembangan dan kemajuan ilmu pengetahuan sangat cepat.

Hal ini terjadi karena mulai tumbuhnya kesadaran manusia terhadap pentingnya ilmu pengetahuan. Ilmu pengetahuan dari waktu ke waktu akan selalu berkembang. Oleh karena itu, sebagai makhluk yang diberi anugerah akal, sepantasnya manusia dapat mengikuti perkembangan ilmu pengetahuan.

Setiap warga negara berhak untuk menikmati pendidikan yang sama dan layak tanpa adanya pembeda antarindividu. Secara umum, pendidikan di Indonesia mencakup pendidikan formal, nonformal dan informal. Pemerintah Indonesia menetapkan wajib belajar formal bagi warganya selama sembilan tahun.Wajib belajar tersebut, terbagi menjadi 2 jenjang, yaitu sekolah dasar (SD) selama enam tahun dan sekolah menengah pertama (SMP) selama tiga tahun.Pendidikan dasar, berorientasi pada masa depan. Untuk mewujudkannya, tentu membutuhkan waktu lama, perlu ada peningkatan dan perbaikan secara berkelanjutan serta kerjasama seluruh komponen pendidikan.

Guru adalah poros utama pendidikan. Ia menjadi penentu kemajuan suatu negara di masa depan. Secara umum, tugas guru adalah mengajar siswa-siswi agar memilki pengetahuan dan keterampilan dalam masing-masing bidang pelajaran. Guru juga merupakan jabatan atau profesi yang membutuhkan keahlian khusus. Guru haruslah menjadi sosok dambaan peserta didik yang senantiasa menjadi teladan yang dicontoh dan ditiru oleh peserta didik dimanapun berada.
Pekerjaan sebagai guru tidak bisa dilakukan oleh seseorang tanpa mempunyai keahlian sebagai guru. Menjadi seorang guru dibutuhkan syarat-syarat khusus, apa lagi jika menjadi seorang guru yang profesional maka harus menguasai seluk beluk pendidikan serta mengajar dengan berbagai ilmu pengetahuan lainnya yang harus dikembangkan melalui masa pendidikan tertentu. Salah satu perubahan yang paling terlihat dari kurikulum 2013 adalah menggunakan pembelajaran tematik dari perubahan standar isi. Pembelajaran tematik merupakan pembelajaran yang mengintegrasikan kompetensi dari berbagai mata pelajaran diintegrasikan kedalam berbagai tema, dan dilakukan pada aspek sikap, keterampilan, dan pengetahuan didalam proses pembelajaran.

Pemahaman guru tentang pembelajaran tematik akan menentukan rancangan rencana pelaksanaan pembelajaran (RPP) dan diterjemahkan dalam bentuk kegiatan pembelajaran. untuk mengatasi hal ini pemerintah berperan penting dalam mempersiapkan seorang guru diantaranya dengan memberikan pelatihan dan memberikan buku pedoman untuk guru. Berapa pun dana yang dikeluarkan pemerintah untuk biaya pendidikan, kalau guru kurang memiliki sikap profesional dan kurang memiliki kompetensi tidak akan tercapai apa yang diharapkan. Salah satu perubahan yang paling terlihat dari kurikulum 2013 adalah menggunakan pembelajaran tematik dari perubahan standar isi. Pembelajaran tematik merupakan pembelajaran yang mengintegrasikan kompetensi dari berbagai mata pelajaran diintegrasikan kedalam berbagai tema, dan dilakukan pada aspek sikap, keterampilan, dan pengetahuan didalam proses pembelajaran.

Pemahaman guru tentang pembelajaran tematik akan menentukan rancangan rencana pelaksanaan pembelajaran (RPP) dan diterjemahkan dalam bentuk kegiatan pembelajaran. untuk mengatasi hal ini pemerintah berperan penting dalam mempersiapkan seorang guru diantaranya dengan memberikan pelatihan dan memberikan buku 
pedoman untuk guru. Berapa pun dana yang dikeluarkan pemerintah untuk biaya pendidikan, kalau guru kurang memiliki sikap profesional dan kurang memiliki kompetensi tidak akan tercapai apa yang diharapkan.

Berdasarkan hasil observasi dan wawancara yang tidak terstruktur telah dilaksanakan di Pahlawan, diperoleh informasi dari kepala sekolah bahwa sekolah baru menerapkan kurikulum 2013 pada tahun ini, dan sekolah tidak langsung menerapkan pembelajaran tematik untuk semua kelas, namun penerapannya dilakukan secara bertahap, dan pada tahun ini kelas yang sudah menerapkan pembelajaran tematik yaitu kelas I dan kelas IV, pada tahun berikutnya kelas II dan kelas V, dan selanjutnya kelas III dan kelas VI. Namun dengan demikian pada masa saat sekarang ini pada masa Pandemi Covid - 19 anak- anak dapat belajar melalui daring dari guru- guru yang ada d Sekolah. Berdasarkan hasil pengamatan observasi yang peneliti lakukan, menemukan beberapa hal yang menjadi kendala dalam pelaksanaan pembelajaran tematik diantaranya dalam penyusunan RPP, karena format RPP kurikulum 2013 berbeda dengan kurikulum yang sebelumnya, kesulitan lain yang dialami oleh guru yakni dalam pelaksanaan proses pembelajaran tematik, dimana pada saat proses pembelajaran yang pada masa Pandemi Covid -19 banyak siswa yang tidak dapat secara keseluruhan mengikuti pembelajaran karna berbagai macam kendala seperti jaringan dari tempat mereka yang susah dapat jaringan dan kendala yang lain.

Pembelajaran tematik mengharuskan guru berperan optimal dalam pembelajaran.Untuk menyiapkan guru ideal dalam pembelajaran tematik pada masa Pandemi Covid -19 ini sangat diperlukanuntuk mengikuti pelatihan khusus untuk guru.Oleh karena itu, guru diwajibkan mengikuti pelatihan agar dengan mudah memahami pembelajaran tematik pada masa pandemi Covid - 19 .

\section{METODOLOGI PENELITIAN}

Penelitian dilaksanakan di SD Pahlawan di Desa Ridan Permai pada masa pandemi Covid19. Penelitian ini menggunakan jenis penelitian fenomenologi, karena penelitian ini bertujuan untuk menggambarkan atau menjelaskan kesiapan guru kelas dalam mengimplementasikan pembelajaran tematik Pada Masa Pandemi Covid - 19 di SDPahlawan. Penelitian fenomenologi mencoba menjelaskan atau mengungkapkan makna konsep atau fenomena pengalaman yang didasari oleh kesadaran yang terjadi pada beberapa individu.Penelitian fenomenologi dilakukan dalam situasi yang alami, sehingga tidak ada batasan dalam memaknai atau memahami fenomena yang dikaji.Hal ini sejalan dengan Littlejohn (2003:184) bahwa penelitian fenomenologi adalah studi tentang pengetahuan yang berasal dari kesadaran, atau cara memahami suatu objek atau peristiwa dengan mengalaminya secara sadar Metode penelitian adalah cara yang digunakan oleh peneliti dalam mengumpulkan data penelitiannya. Metode yang digunakan peneliti dalam penlitian ini adalah penelitian tindakan kelas.

Penelitian Tindakan Kelas umumya disingkat dengan PTK atau Classroom Action Research (CAR).Menurut Arikunto, (2014:58), penelitian tindakan kelas adalah penelitian tindakan yang dilakukan di kelas dengan tujuan memperbaiki/meningkatkan mutu praktik pembelajaran. Penelitian tindakan kelas juga merupakan suatu penelitian yang dikembangkan berdasarkan permasalahan yang muncul dalam kegiatan pembelajaran yang bertujuan unutk memperbaiki dan meningkatkan proses belajar mengajar di kelas. Sedangkan Menurut Kunandar, (2011:46) penelitian tindakan kelas adalah suatu kegiatan ilmiah yang dilakukan oleh guru di kelasnya sendiri dengan jalan merancang, melaksanakan, mengamati, dan merefleksikan tindakan melalui beberapa siklus secara kolaboratif dan partisipatif yang bertujuan untuk memperbaiki atau meningkatkan mutu proses pembelajaran di kelasnya.

\section{Sumber Penelitian}

Subjek penelitian diambil satu kelas yaitu kelas semester ganjil, pengambilan kelas yang dijadikan subjek penelitian ini dilakukan berdasarkan pertimbangan bahwa kelas II SD Pahlawan. 


\section{Teknik Pengumpulan Data}

Menurut Sugiyono (2012:309) dalam penelitian dan teknik pengumpulan data yang lebih banyak pada observasi berperan serta (participan observation), wawancara mendalam (in depth interview), dan dokumentasi.Dalam penelitian ini, teknik pengumpulan data yang digunakan yaitu observasi, wawancara dan dokumentasi.

\section{Observasi}

Nasution mendefinisikan dalam Sugiyono (2012:310) obervasi adalah dasar semua ilmu pengetahuan.Para ilmuwan hanya dapat bekerja berdasarkan data, yaitu fakta mengenai dunia kenyataan yang diperoleh melalui observasi.Data itu dikumpulkan dan sering dengan bantuan alat yang sangat canggih, sehingga benda-benda yang sangat kecil maupun yang sangat jauh dapat diobservasi dengan jelas.

Dalam penelitian hal ini, peneliti akan mengadakan peninjauan langsung kelapangan, peneliti hanya sebagai pengamat yang mencatat, menganalisis dan membuat kesimpulan mengenai permasalahan yang berkaitan dengan kesiapan guru kelas dalam mengimplementasikan pembelajaran tematik.

\section{Wawancara}

Wawancara adalah metode pengambilan data dengan cara menanyakan sesuatu kepada seseorang yang menjadi informan atau responden (Afifudin dan Beni Ahmad Saebani, 2012:131). Sedangkan menurut Esterberg dalam Sugiyono (2012:317) mendefinisikan wawancara adalah pertemuan dua orang untuk bertukar informasi dan ide melalui tanya jawab, sehingga dapat dikontruksikan makna dalam suatu topik tertentu.

Wawancara dilakukan dengan bertatap muka dengan informan.Ada pun yang menjadi informan dalam penelitian ini adalah guru kelas dua. Kemudian, dilanjutkan dengan kepala sekolah dan siswa guna untuk mendapatkan data yang obejektif mengenai kesiapan guru kelas dalam mengimplementasikan pembelajaran tematik di SD Pahalwan.

\section{Dokumentasi}

Menurut Sugiyono (2012:329) dokumentasi adalah catatan peristiwa penting yang sudah berlalu.Dokumentasi bisa berupa tulisan, gambar, atau karya-karya misalnya catatan harian, ceritera, biografi, peraturan, kebijakan.Studi dokumen merupakan pelengkap dari penggunaan metode observasi dan wawancara dalam penelitian kualitatif.

\section{Teknik Analisis Data}

Teknik analisis data dibutuhkan peneliti untuk menganalisis data yang diperoleh dapat dipahami. Data dalam penelitian kualitatif dianalisis secara terus-menerus, mulai dari perumusan masalah, saat terjun dilapangan, hingga penulisan hasil penelitian atau mengelolah data-data yang telah didapatkan dilapangan sehingga dapat dimengerti oleh peneliti maupun orang lain. Sugiyono (2012:335) menyatakan bahwa analisis data adalah :Proses mencari dan menyusun secara sistematis data yang diperoleh dari hasil wawancara, catatan lapangan, dan dokumentasi dengan cara mengorganisasikan data kedalam kategori, menjabarkan kedalam unit-unit, melakukan sintesa, menyusun kedalam pola, memilih mana yang penting dan yang akan dipelajari, dan membuat kesimpulan sehingga mudah dipahami oleh diri sendiri maupun orang lain. Analisis data dalam penelitian kualitatif dilakukan sejak sebelum memasuki lapangan, selama dilapangan, dan setelah selesai dilapangan. Tetapi dalam penelitian kualitatif, analisis data lebih difokuskan selama proses dilapangan bersamaan dengan pengumpulan data. Pada saat tahap pengumpulan data, peneliti harus melakukan analisis terhadap data yang telah didapat, bila data yang didapat setelah dianalisis terasa belum memuaskan, maka peneliti akan melanjutkan mencari data sampai tahap tertentu, agar memperoleh data yang dianggap kredibel. Hal ini sejalan dengan pendapat Miles dan Hubermen dalam Sugiyono (2012:337) bahwa aktivitas dalam analisis data kualitatif dilakukan secara interaktif dan berlangsung secara terus menerus sampai tuntas, sehingga datanya sudah jenuh. Analisis penelitian ini menggunakan model interaktif atau Model Miles dan Hubermen.Langkah-langkah analisis data tersebut dimulai dari tahap reduksi data, penyajian data, dan penarikan kesimpulan dan verifikasi. 


\section{Reduksi Data (Data Reduction)}

Data yang diperoleh dari lapangan jumlahnya cukup banyak, untuk itu maka perlu dicatat secara teliti dan rinci. Makin lama peneliti kelapangan, maka jumlah data akan makin banyak, kompleks dan rumit. Untuk itu perlu segera dilakukan analisis data melalui reduksi data.

Menurut Sugiyono (2012:338) mereduksi data berarti merangkum, memilih hal-hal yang pokok, memfokuskan pada hal-hal yang penting, dicari tema dan polanya dan membuang yang tidak perlu. Dengan demikian data yang telah direduksi akan memberikan gambaran yang lebih jelas, dan mempermudah peneliti untu melakukan pengumpulan data selanjutnya, dan mencarinya bila diperlukan.

Dalam penelitian ini, dapat dilakukan reduksi data yang diperoleh dari hasil wawancara, observasi, dan dokumentasi mengenai kesiapan guru kelas dalam mengimplementasikan pembelajaran tematik di SDN 029 Sumber Makmur.

\section{Penyajian Data (Data Display)}

Setelah data direduksi, maka langkah selanjutnya adalah mendisplaykan data. Sugiyono (2012:341) menjelaskan bahwa melalui penyajian data, data terorganisasikan, tersusun dalam pola hubungan, sehingga akan semakin mudah dipahami. Dalam penelitian kualitatif, penyajian data bisa dilakukan dalam bentuk uraian singkat, bagan, hubungan antar kategori, flowchart dan sejenisnya. Melalui mendisplaykan data, maka akan memudahkan untuk memahami apa yang terjadi, merencanakan kerja selanjutnya berdasarkan apa yang telah dipahami. Data dalam penelitian ini disajikan dalam bentuk teks narasi.

\section{Penarikan Kesimpulan dan Verifikasi (Conclusion Drawing and Verification)}

Langkah ketiga dalam analisis data kualitatif menurut Miles dan Huberman adalah penarikan kesimpulan dan verifikasi. Sugiyono (2012:345) menerangkan bahwa kesimpulan dalam penelitian kualitatif dapat menjawab rumusan masalah yang dirumuskan sejak awal atau rumusan masalah yang telah disampaikan.

\section{HASIL PENELITIAN DAN PEMBAHASAN}

Hasil observasi Kesiapan guru kelas pada pertemuan I masih banyak kelemahan yang perlu diperbaiki pada pertemuan selanjutnya, yaitu: 1) Guru memberikan apersepsi berupa pertanyaan siswa terlihat antusias dan sebagian siswa yang semangat. 2) Guru menyampaikan tujuan pembelajaran sesuai dengan indicator tetapi tidak jelas sehingga siswa kurang mengerti dan memahami.3) Guru membagi LTS, tetapi tidak semua siswa yang mengerjakan LTS tesebut. 4) Guru kurang meminta siswa bekerja sama dalam kelompok. 5) Guru kurang memberikan waktu untuk siswa mengamati masalah lingkungan alam dalam diskusi kelompok. 6) Guru kurang teliti dalam permainan cabut undian, nama kelompok yang kuar selalu sama. 7) Guru kurang meminta siswa mempresentasikan hasil diskusinya. 8) Guru kurangmemberikan pengarahan untuk siswa yang menanggapi pertanyaan dari kelompok yang menjawab. 9) Guru kurang memberikan penguatan kepada siswa. 10) Guru kurang memberikan kesempatan kepada siswa menyimpulkan materi pembelajaran. Aktivitas guru dalam proses belajar dapat diamati dengan menggunakan lembar observasi pada setiap pertemuan yang dilakukan oleh observer.

Pada Siklus I pertemuan 2 Kesipan guru kelas lebih baik dari pertemuan 1, yaitu: 1) Guru memberikan apersepsi berupa pertanyaan beberapa siswa sudah terlihat antusias dan sebagian siswa semangat. 2) Guru menyampaikan tujuan pembelajaran sesuai dengan Indikator dengan jelas dan sudah mengerti dan memahami. 3) Guru memberi pertanyaan kepada siswa dan siswa bersemangat menjawab pertanyaan dan menanggapi. 4) Guru membagi LTS dan sebagian besar siswa sudah mengerjakan LTS tersebut.5) Guru memberikan permainan cabut undian untuk siswa menjawab pertanyaan dan menanggapi dengan semangat. 6) Guru meminta siswa mempersentasikan di depan kelas dan siswa dengan suara yang keras. 7) Guru dan siswa menyimpulkan materi pembelajaran dengan singakt dan jelas. Lembar observasi aktivitas guru siklus I pertemuan 2 Kesiapan Guru Kelas deskripsi dengan menganalisis kesiapan guru kelas dalam mengimplementasikan Pembelajaran tematik di Masa Pandemi Covid-19 di SD Pahalwan. Semua aspek menunjukkan muncul ya 
atau tidak tetapi setiap aspek memiliki komentar yang berbeda.

\section{SIMPULAN}

Kesiapan guru kelas dalam mengimplementasikan pembelajaran Tematik di SD pahalwan dapat dijadikan sebagai bahan acuan untuk mengadakan penelitian selanjutnya dari sudut permasalahan yang berbeda. Selain itu dapat diimplementasikan sebagai bahan kajian pendekatan pembelajaran bagi guru untuk diterapkan di SD Pahalwan Di Desa Riden Permai. Dengan ini Perlunya kerja sama antara Guru Kelas dan orang tua dalam tercapainya tujuan pembelajaran di masa pandemi. Orang tua mendampingi anak untuk belajar di rumah dan beradaptasi pada masa pandemi. Dan bagi Guru dapat menerapkan pembelajaran Tematik ini di masa pandemi Covid- 19

\section{DAFTAR PUSTAKA}

Aditya, N. I. M. (2017). Kesiapan Mahasiswa Program Studi Pendidikan Matematika dalam Menempuh Mata Kuliah Magang 3 di SMK Negeri 9 Surakarta Tahun 2015/2016. Skripsi (Naskah Publikasi). Pendidikan Matematika Fakultas Keguruan dan Ilmu Pendidikan
Universitas Muhammadiyah surakarta. UMS Press.

Alma, B., Mulyadi, H. H., Razati, G., dan Nuryati, B. L. (2009). Guru Profesional (Menguasai Metode dan Terampil Mengajar). Bandung: Alfabeta.

Anonim. 2017. Buku Pedoman Magang 3. Surakarta: Laboratorium Microteaching \& Magang Universitas Muhammadiyah Surakarta.

Asril, Z. (2011). Micro Teaching Disertai dengan Pedoman Pengalaman Lapangan Edisi 1 Cetakan Ketiga. Jakarta: PT RajaGrafindo Persada

Hasbullah .(2013). Dasar-dasar Ilmu Pendidikan (Edisi Revisi).Jakarta: PT Rajagrafindo Persada.

Kadir, A, dan Asrohah, H. (2014).Pembelajaran Tematik. Jakarta: PT Rajagrafindo Persada.

Malawi, I, dan Kadarwati, A. (2017).Pembelajaran Tematik (Konsep dan Aplikasi). Jawa Timur: CV AE Media Grafika.

Meleong, L. J. (2012). Metodologi Penelitian Kualitatif. Bandung : PT Remaja Rosdakarya.

M. W. (2010). Kompetensi Guru Sebagai Pendidikan.Jurnal Falasifa. Vol 1, (1), 